\title{
The Public Relations Activities of Taman Impian Jaya Ancol, Ldt in Promoting Jakarta Tourist Attraction
}

\author{
Afrilia Christina Ariani ${ }^{*}$ and Novi Erlita \\ Fakultas Ilmu Komunikasi, Universitas Mercu Buana, Jl. Meruya Selatan No.1, RT.4/RW.1, Meruya Sel., Kec. Kembangan, Kota Jakarta Barat, Daerah \\ Khusus Ibukota Jakarta 11650, Indonesia
}

\author{
DOI: $\underline{10.36348 / \text { sihss.2019.v04i11.004 }}$ \\ | Received: 05.11.2019| Accepted: 13.11.2019| Published: 24.11.2019
}

*Corresponding author: Afrilia Christina Ariani

\section{Abstract}

Tourist Attractions that have a variety of recreational segments include several business units, namely Taman Impian, Dunia Fantasi, Atlantis Water Adventure, Ocean Dream Samudra, Seaworld Ancol and Ancol Ecopark, meanwhile, the resort segment includes the Putri Duyung Ancol and Bidadari Eco Resort. In addition, this place had never quiet, because every day, there are a lot of visitors. Taman Impian Jaya Ancol, Ltd Owns the role of public relations under the Corporate Secretary division. The responsiblities include building good relations between management or internal public and external public, namely consumers so that this good relation could create a good understanding both the parties. They must also be able to develop skills in getting information from various sources and they must be able to develop relationships and cooperation with all company divisions, so that the solid team work is formed. By this background, it is not easy absolutely to keep the number of visitors based on the company target with the emerge of similar tourist attractions. Hence, the researchers are interested in discussing this problem in the form of research entitled "Public Relations Activities of Taman Impian Jaya Ancol, Ltd in Promoting Jakarta Tourist Attraction.

Keywords: Tourist Attaction, Public Relatiosn, Promotion.

Copyright @ 2019: This is an open-access article distributed under the terms of the Creative Commons Attribution license which permits unrestricted use, distribution, and reproduction in any medium for non-commercial use (NonCommercial, or CC-BY-NC) provided the original author and source are credited.

\section{INTRODUCTION}

Taman Impian Jaya Ancol, Ltd owns the role of public relations under the Corporate Secretary division. The responsiblities include building good relations between management or internal public and external public, namely consumers, so that this good relation could create a good understanding both parties. They must also be able to develop skills in getting information from various sources and they must be able to develop relationships and cooperation with all company divisions so that solid team work is formed.

The tight competitive competition in the world of tourism at this time encourages Taman Impian Jaya Ancol, Ltd to create a marketing strategy that aims to maintain the number of visitors, because consumers will take the decision to choose the tourist attraction. If the tourism has a good reputation and attractive attitude, then it hopes to create the loyalty of visitors to visit the place again and they also recommends other visitors by positive recommendations to visit this place.

Hence, the researchers are interested in examining the phenomena that occur at Taman Impian
Jaya Ancol, Ltd, especially the business units where tourism sites have a seductive appeal so that they always bring visitors every day even the day is not holiday, such as dufan and atlantis. In the Public Relations section, is there a separate strategy that is able to maintain the existence and number of visitors by conducting research in the early period of the year in January-March 2018.

As a management tool, public relations can be said as a management tool designed to build a variety of support both internal and external to the company. In addition, public relation also needs to build a positive image of the company through various publicity and communication activities with various stakeholders [1]. Besides, the public relation is generally associated with communication activities that are designed to create and maintain the image and good relations of the organization with the public [2]. Thus, public relation can play a role in helping companies to promote various company programs.

Based on the description of research background, the focus of research is on how the Public 
Relations activities of Taman Impian Jaya Ancol, Ltd in promoting the Jakarta tourist attractions are. This research aims to map, find out, and describe how the public relation as the public information media could build trust and reputation of Taman Impian Jaya Ancol, Ltd in Promoting Jakarta Touris Attraction. In addition, this research is expected to be used as recommendations for communication innovation, regarding how the process of Taman Impian Jaya Ancol, Ltd in promoting the Jakarta tourist attractions.

\section{LITERATURE REVIEW \\ Public Relations}

Rex Harlow explains that Public Relations is a management function that is distinctive and supports coaching, maintaining a common path between an organization and its community, concerning communication activities, understanding, acceptance and cooperation; involving the management in dealing with problems, helping the management to face public opinion; supporting management in following and utilizing change effectively; acting as an early warning system in anticipating trends on the use of research, and communication techniques, such as good and ethical communication as a primary means [3].

Public relations as a management and communication discipline needs to understand that they are strongly influenced by information and communication technology, especially in the last decade. At present, Public Relations cannot avoid dealing with the digital media, social media, and cell phones. These media are part of the works that will become one of the drivers of new work within the scope of Pulic Relations work [4].

To achieve the promotion objectives, the communication strategies of the promotors are facilitated by the existence of social media in communication activities. Social media can function as a network agent and a window for criticism and suggestions [5]. The implementation of social media promotion can be beneficial for the company, such as, first, it can reach more people in a shorter time. Thus, many consumers can be reached because of extensive social media penetration. Thus, they could receive information about the product company (new). Second, the spread of positive words through social networks can influence the decision making of potential customers and might increase their purchase intentions [6].

The purpose of Public Relations based on internal relations activities in this case may include several things, namely: (1) Conducting an assessment of the attitude, behavior, and public opinion of the company, especially related to the company policy that is being carried out, (2) Conducting an analysis and improvement of policies that are being carried out in order to achieve the goals set by the company by unforgetting the interests of the community, (3) Providing information to the employee about a company policy that is objective and related to various routine company activities which also explains the company's development. In the next stages, it is hoped that the employee will remain well informed, (4) Planing for the preparation of an effective staff for the assignment of activities that are compounded by Internal Public Relations within the company [7].

Then, the purpose of Public Relations, based on external relations activities, is intended to get support from the public. The understanding of public support is limited to the understanding of: (1) Expanding subscription or marketing, (2) Introducing a type of production or idea that is useful for the community in a broad sense, (3) Finding and developing capital (4) Improving the company's image of opinions wider community, in order to get positive public opinion [7].

The responsiblities of Public Relations is not limited only to take care of the image and public opinion. However, it also involves some responsiblities. According to Kusumastuti, there are three responsiblities of Public Relations in the organization: 1) Interpreting, analyzing, and evaluating public trends, which then resported to the management to formulate organization/institution policies, 2) Reconciling the interests of organizations / institutions with the interests of the public. The interests of the organization / institution can be much different from the public interests and on the contrary. However, it can also be a little different or even the same interests, and 3) Evaluating the programs of the organization/institution, especially related to the public. The responsiblities of evaluating this management program requires a high and broad PR position and authority [7].

Public Relations activities are also closely related to corporate communication. Communication is a process of delivering information (messages, ideas) from one party to another. A company must communicate with other parties or the public, both internal (employees and shareholders) and external (media, government and associations and the general public) related to the activities that seek to establish public relations are known as corporate.

\section{Public Relations Marketing}

Public Relations Marketing is a marketingoriented concept of Public Relations. Before and after marketing is run, it needs to be accessed or maintained by Public Relations by forming a positive image of a product or service. If the company's image, product, and service are positively built in the public opinion, it will facilitate public marketing efforts to attract the customers [8]. 
To achieve the success of Public Relations, according to Rhenald Kasali in his book Public Relations Management, a Public Relations practitioner can take the following steps: 1) Conveying facts and opinions, both circulating inside and outside the company. 2) Browsing through official company documents or study changes that occur historically. Changes are generally accompanied by changes in company attitudes towards the public or so on. This is done in order to understand the vision and mission and the initial purpose of the establishment of company. Hence, if there is a change, it can be immediately known, 3) Conducting a SWOT analysis including strengths, weaknesses, opportunities, and threats. Although there is no need to analyze things that are out of his reach, a public relations practitioner needs to do a meaningful analysis of perceptions from outside and within the company of his SWOT [9].

\section{Tourist and Tourist Attraction}

According to the International Union of Official Travel Organizations (IUOTO), tourist is a person who comes to a country or other place of residence and usually for any purpose except to do work that receives wages. This touris can be further divided into: 1) International (Overseas), Tourist is a person who travels outside of his country and the country, 2) National Tourist (Domestic) is an Indonesian resident who travels in the territory of Indonesia outside his domicile, within a period of at least 24 hours or overnight except for activities that bring income to the place visited [10].

According to Law Number 10 of 2009, mentioning Tourist attraction/Tourism is everything related to tourism, including the management of tourist attraction, promotion, and businesses related to the implementation of tourism, thus tourism includes: 1) All activities related to travel, 2) Management of tourist attraction and attractions such as: tourist areas, recreational parks, historical heritage areas, museums, cultural arts performances, community or natural life arrangements: natural beauty, volcanoes, lakes, beach, and 3) Tourism business services and facilities, namely: tourism service businesses (travel agents, travel agents, conventions, incentive trips and exhibitions, tourism consultants, tourism information). Business tourism facilities consists of accommodation, restaurants, bars, tourist transportation.

\section{METHODOLOGY}

This study used a qualitative method. This study used descriptive qualitative method. According to Bodgan and Taylor, this type of research produced descriptive data in the form of written or oral words from people and observable behavior. Thus, the research reports were in the form of data excerpts to illustrate the presentation of the report. The data were interview scripts, field notes, photos, videotapes, personal documents, notes or memos, and other official documents. At the time of writing the report, the researchers analyzed very rich data and as far as possible in its original form [11].

The research object is the Corporate Communication Manager of Taman Impian Jaya Ancol, Ltd and the Secretary of the Corporate Relations \& Media Promotion Section which are key informants in the formation and implementation of strategies. To get additional informants, the tourist is also involved to use their point of view through in-depth interviews directly and naturally. In addition, other research subjects came from Community Leaders, sociologists, economists, academics, practitioners, tourism industry, communicators).

To ensure that the research data is valid, a data validity checking process was carried out. Related to this validity, Miles and Huberman explained that the technique of checking data validity includes three concurrent activities: data reduction, data presentation, and drawing conclusions (verification). Then, to establish the validity of the data, the researchers conducted a triangulation of source techniques [12]. According to Moleong, comparing and checking back the degree of confidence of the information was obtained by: (1) comparing the observation data with interview data (2) comparing the consistency of the respondent's answers, namely by comparing what the resource person said in public, for example, with what was said personally (3) comparing one's perspective, with others in his work team [13].

\section{DISCUSSION}

Based on the results of research that the researchers have explained in the previous sub-chapter, the researchers can find out that the strategy carried out by Taman Impian Jaya Ancol, Ltd was in accordance with the planning that has been explained by the Corporate Communication that it has a good strategic concept so that it runs according to the initial plan.

In the following chapter, the researcher enters into the next stage which is the discussion. In research conducted by researchers on the Public Relations Strategy of Taman Impian Jaya Ancol, Ltd in maintaining the number of tourist visitors through the promotion program. The strategy carried out by public relations aims to maintain the number of existing tourist visitors and even make an increase and provide satisfaction for visitors to keep coming back. The public relations strategy that was carried out is packaged into a form of programs that are sustainable or sustainable where the strategy continued to run until the time which has been determined by the company. Thus, the current strategy will responsible in maintaining the number of tourist visitors.

From the results of research interviews conducted by the researchers with Rikha Lestari and 
Ms. Novi as Corporate Communication Manager and Secretary of the Head of Media Relations \& Corporate Promotion PT. Taman Impian Jaya Ancol, Tbk, the researchers identified a strategy carried out by PR on how they maintained the number of visitors to their tourism and build awareness in the eyes of the public in order to promote Ancol as a choice of various tourist attractions. Relationship between Public Relations and strategy is that who runs the strategy and manage it together with the leader is a Public relations practitioner.

As the result, the Public Relations practitioner has a responsiblity to oversee every activity inside and outside the company. In addition, to strengthen the research data, it also refers to the concept applied by Rhenald Kasali who applies the three steps taken by PR to contribute in developing strategies to public relations strategies in maintaining the number of tourist visitors through promotional programs.

First, conveying facts and opinions, this is done in order to obtain data about the public's view.

Secondly, trace the company's official documents or study changes that occur historically. this is done in order to understand the vision and mission and the initial purpose of establishing the company so that if changes occur can be immediately known, third, conducting a SWOT analysis, so a PR practitioner needs to carry out a weighted analysis regarding perceptions from outside and within the company of its SWOT.

Taman Impian Jaya Ancol, Ltd has carried out the planned strategy with the aim of maintaining the number of visitors to the tour and providing additional value, namely awareness of the people who are or will be visitors. The company hopes that this strategy can provide new experiences for tourism visitors who have become the target of the company's strategy. This is a certainly part of the company's business strategy to become a company that is better known to the public.

As explained in the results, Taman Impian Jaya Ancol, Ltd can make a strategy that starts by looking at the potential of the company and what is needed by the company that can later be used as data by the Corporate communication in making the next strategy, because the strategy is essentially planning (planning) and management (management) to achieve a goal.

Secretary of the Division of Media Relations \& Corporate Promotion Section delivered the Taman Impian Jaya Ancol, Ltd objectives through a promotion program are usually different every season or on special days and dates. Everything done by PR must always uses good communication measures. How does public relations communicate with all parties and visitors, because communication is the stage of the strategy carried out by a publicist. After the deliberations and discussion results that have been approved by Corporate Communication, they determined the right program with the strategy that was formed, therefore Ancol directly communicates the results of the discussion with the units in the company, because the target of the existing strategy is the survival of the number of tourist visitors and public awareness of Ancol.

When researchers meet with tourist visitors, they got information that the strategies formed by Corporate communication were applied to unit programs which were directly accepted by visitors who get information from online media so they come to visit Ancol. As has been explained, communication is a form of interaction between fellow human beings, so in carrying out each activity certainly has a goal to be achieved as well as communication activities conveyed by Onong Uchyana Effendy [14] the purpose of communication is change in attitude, change in opinion, change in behavior, and social transformation.

By the purpose of communication the public relations of Taman Impian Jaya Ancol, Ltd, they can get closer and can indirectly persuade visitors to continue to visit Ancol. The public relations represented by the corporate communication division also communicated through social media or call centers in questions, comments / reviews. Thus, it designed to know the shortcomings of the program and can be improved according to the needs of visitors. In accordance with the function of public relations, namely activities aimed at obtaining good faith, trust, mutual understanding of the public or the community. In addition, there are some visitors who do not know clearly about the programs created by Ancol units, they complained that they only found out about the promotion when they arrived at Ancol.

Based on the results of interviews with the Corporate Communication for the evaluation results, there is an increase in tourist visitors, so that after the program runs, the increase was improved. Hence, you could say this strategy has helped a lot in maintaining the number of tourist endorsers in Ancol. In the Public Relations strategy, the results of this evaluation become the final stages of program management whether it has been achieved properly or not, and become the basis for further activities. The evaluation conducted by Corporate Communication has been achieved well in accordance with Ms. Rika Lestari excerpt related to the annual pass program that they run, because the company is able to see simply the enthusiastic visitors toward Ancol.

This company in the future will continue to make innovations from existing programs and make innovations into their leisure business units, because people usually consider Ancol by the public current 
view. In fact, Ancol has changed the concept that every visitor who comes will feel a new experience, because Ancol has become the center of attention with existing facilities and satisfactory promo program in accordance with the responses of visitors in maintaining the number of tourist visitors or even it increased the number of tourist visitors and be able to compete with other attractions.

Public Relations Program of Taman Impian Jaya Ancol, Ltd, nowadays, often issues promotions from each of its recreation business units to attract customers with discounts or visit discounts. Ancol will usually be crowded with visitors when the promo program is issued based on the season. Thus, you will see the number of tourist visitors and an increase in tourist visitors. As stated by Rosady Ruslan [15] that, there are four strategies in public relations activities in designing a message in the form of information or news, namely strategy of publicity, strategy of persuation, strategy of argumentation, and strategy of image. In this case, the Public Relations of Taman Impian Jaya Ancol, Ltd represented by the Corporate Communication division, carries out a strategy of publicity which means conducting a promotion to spread the message of the promo program through the process of publishing news through collaboration with various mass media.

\section{CONCLUSION}

The research related to Public Relations Strategy of Taman Impian Jaya Ancol, Ltd In Maintaining the Number of Tourism Visitors Through the Promotion Program concluded that the Public Relations Strategy conducted by the Public Relations of PT. Taman Impian Jaya Ancol, Tbk was using one of the communication media, namely social media and publications through websites and other media, such as having partners with e-commerce providers. In this case, Taman Impian Jaya Ancol, Ltd carried out a strategy of publicity which means conducting a promotion to spread the message of the promo program through the process of publishing a news through collaboration with various mass media. The Public Relations made promotion programs in accordance with the leisure business units they have based on the season, such as the Eid holiday season and Christmas and New Year. The purpose of the program is to maintain the number of tourist visitors, increase the number of visitors, and also builds better awareness. In addition, the PR of PT. Taman Impian Jaya Ancol, Ltd communicates with tourism visitors through Ancol's customer care services to respond to questions regarding promotional programs, reviews or appreciation toward these reviews to know the shortcomings of the strategies made and to find out what the visitor want to.

\section{REFERENCES}

1. Rivero, O., \& Theodore, J. (2014). The importance of public relations in corporate sustainability. Global Journal of Management and Business Research, 14(4).

2. Prindle, R. (2011). A Public Relations Role in Brand Messaging. International Journal of Business and Social Science, 2(18).

3. Yuliawati, I., \& Enjang, P. (2018). The Analysis of Green Environment Movement Campaign in Supporting National Food Security of Indonesia. Global Journal of Human-Social Science, 18(2).

4. Verčič, D., Verčič, A. T., \& Sriramesh, K. (2015). Looking for digital in public relations. Public Relations Review, 41(2), 142-152.

5. Rowe, A. D., \& Pitfield, D. E. (2018). The challenge facing existing airport campaign groups when incorporating social media into their campaign: A social network analysis of Airport Watch's social media utilisation. Geoforum, 96, 236-247.

6. Baum, D., Spann, M., Füller, J., \& Thürridl, C. (2019). The impact of social media campaigns on the success of new product introductions. Journal of Retailing and Consumer Services, 50, 289-297.

7. Djaja, D. (1985). Peranan Humas Dalam Perusahaan. Bandung: Penerbit Alumni.

8. Ardianto, E. (2010). Metode Penelitian Untuk Public Relations: PT. Remaj Rosdakarya.

9. Kasali, R. (2003). Manajemen Public Relations: Konsep dan Aplikasinya di Indonesia. Jakarta: PT. Pusaka Utama Grafiti.

10. Pendit, N. S. (1999). Ilmu Pariwisata Sebuah Pengantar Perdana, Jakarta: PT. Pradnya Paramita.

11. Jamil, A., \& Irawan, E. P. (2018). The Analysis of Lebak Smart City Application Based on Mobile in Improving Lebak Regency Government Service. International Journal of Sciences: Basic and Applied Research (IJSBAR), 39(2), 149-164.

12. Kurniastuti, K. (2018). Activities of the Cyber Public Relations of $\mathrm{O}$ Chanel TV in Promoting their Company on the Instagram Social Media. American Journal of Humanities and Social Sciences Research. 2(9), 50-56.

13. Yuliawati. (2019). The Program Evaluation of the Green Environment Movement Campaign to Support the National Food Security (A Case Study of the Evaluation of Green Environment Program through Hydroponic Plants by Military District Command 0503 West Jakarta). International Journal of Humanities and Social Science Invention (IJHSSI); 8(8).

14. Uchjana, O. (1990). Ilmu Komunikasi Teori dan Praktek. Bandung: PT. Remaja Rosda karya.

15. Rosady, R. (2010). Manajemen Public Relations \& Media Komunikasi. Jakarta: Raja Grafindo Persada. 